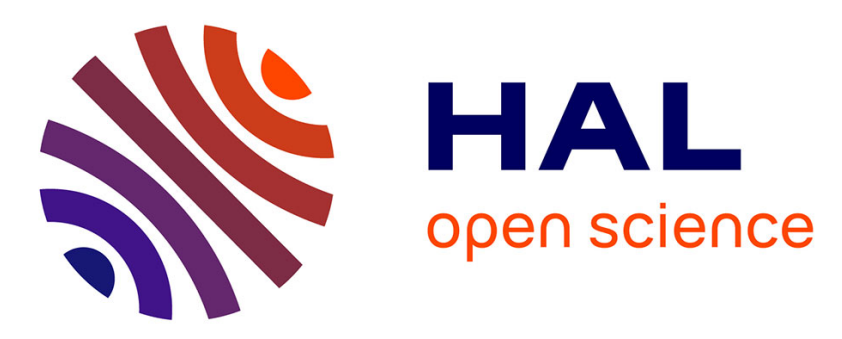

\title{
Instant messaging, digital writing and spelling production quality in French
}

Aurélie Simoës-Perlant, Tonia Lanchantin, Cecilia Gunnarsson-Largy, Pierre Largy

\section{- To cite this version:}

Aurélie Simoës-Perlant, Tonia Lanchantin, Cecilia Gunnarsson-Largy, Pierre Largy. Instant messaging, digital writing and spelling production quality in French. Lingvisticae Investigationes Supplementa, 2018, 41 (2), pp.161-178. 10.1075/li.00018.sim . hal-01998841

\section{HAL Id: hal-01998841 https://hal.science/hal-01998841}

Submitted on 13 Feb 2019

HAL is a multi-disciplinary open access archive for the deposit and dissemination of scientific research documents, whether they are published or not. The documents may come from teaching and research institutions in France or abroad, or from public or private research centers.
L'archive ouverte pluridisciplinaire HAL, est destinée au dépôt et à la diffusion de documents scientifiques de niveau recherche, publiés ou non, émanant des établissements d'enseignement et de recherche français ou étrangers, des laboratoires publics ou privés. 


\title{
Instant messaging, digital writing and spelling production quality in French. A cognitive approach
}

\author{
Aurélie Simoës-Perlant ${ }^{\mathrm{a}}$, Tonia Lanchantin ${ }^{\mathrm{b}}$, Cecilia Gunnarsson-Largy ${ }^{\mathrm{b}}$, \\ Pierre Largy \\ ${ }^{a}$ Laboratoire CLLE CNRS UMR5263, Université de Toulouse Jean Jaurès, 5 \\ Allée Antonio Machado, 31058 Toulouse Cedex 9, France \\ ${ }^{b}$ Laboratoire OCTOGONE-Lordat, EA4156, Université de Toulouse Jean \\ Jaurès, 5 Allée Antonio Machado, 31058 Toulouse Cedex 9, France
}

\begin{abstract}
The increased use of digital writing led to the appearance of written content that may differ from the standards of spelling. Writing instant messages leads to the production of two different types of written forms that differ from standard spelling: (a) those that can be confused with misspellings and (b) those that cannot. We showed that the production of the second type of modifications has no effect on spelling production. Our research protocol allowed comparing two corpura (written in 1974 and 2012). These results showed that when a modification has no orthographic equivalent, its use cannot damage the quality of spelling production. When it does, the effect on spelling may be negative.
\end{abstract}

Keywords: standard writing; instant messaging; adolescent; spelling; digital writing.

\section{Introduction}

Instant and text messaging correspond to a new way of writing that is referred to as digital writing. New written forms (e.g. abbreviations and smileys) have appeared, since they meet the requirements for digital communication (e.g., time saving). The more or less important use of these written forms is linked to the spatio-temporal context (e.g., the place where the message is written, the time available to the user) and the social context (e.g. the recipient of the message, implicit social codes). These new forms sometimes differ from the standards of spelling. Their eventual negative impact on the quality of spelling is currently debated. The question here is to establish whether the use of these forms has consequences on the spelling production. If there are consequences, all types of modifications will probably not have the same effect.

\section{Writing using digital media: between standard and digital writing}




\subsection{How do we produce written content?}

Writing to communicate with a known interlocutor on computers, tablet computers, cell phones, etc. differs from writing on a sheet of paper. Sometimes, a user chooses not to follow the standards of spelling when s/he writes on a digital device. That is why the difference between standard and digital writing has to be made. The first refers to writing while trying to follow the standards of spelling as much as possible; the second to writing while trying to circumvent these standards to better meet the requirements for communication. It means that everything relies on the user's choice: if $s /$ he does not want to use digital writing to write text or instant messages, $s /$ he is free to produce standard writing on a digital device. But both still concern the act of writing as users write letters and mobilize cognitive processes to communicate.

Generally speaking, written production is a cognitive process that includes three steps: (a) "pre-writing", where words have not yet appeared on paper; (b) "writing", where people actually produce writing; and (c) "re-writing", where people rework the written content (Hayes \& Flower, 1980). In other words, the first step allows defining the conceptual aspect of the message that has to be delivered; the second allows changing thoughts into syntactic and lexical elements. These operations consist of the selection of the linguistic and paralinguistic marks which translate the semantic, pragmatic and textual choices leading to the actual writing; and the third consists of unifying the written text by reflecting different kinds of goals along the hierarchy upon the written text. This cognitive process is not linear, but recursive.

It is somewhat reminiscent of how human memory is structured as it fits perfectly with the production of speech and written content, and especially how working memory is structured. Working memory is divided into four different parts (i.e. the central executive; the phonological loop, the visuospatial sketchpad, and the episodic buffer, Baddeley \& Hitch, 1974; Baddeley, 2000). The phonological loop deals with speech and written content; the visuospatial sketchpad stores and processes information in visual and/or spatial form(s); and the episodic buffer allows making the connection between working memory elements and knowledge stored in the orthographic lexicon, which is a part of long-term memory.

When it comes to the implication of working memory in the writing process, both leading writing models account for this implication since 1996, Hayes in a revised version of the Hayes and Flower model (1980) and Kellogg when presenting his writing model. These different steps highlight the need for long-term memory, where knowledge (that relates to the grapheme-to-phoneme correspondence and to the standards of spelling) is stored. The grapheme-to-phoneme correspondence relies on two linguistic components: (a) phonemes, which are defined as the smallest sound 
units of a language and (b) graphemes, which are their graphic equivalents (Cellier, 2003). When someone acquires knowledge about this correspondence, s/he becomes able to produce written content. For languages with a deep orthography where the phoneme-to-grapheme correspondence may sometimes make things more difficult to understand and to produce (e.g.: /krizãtem/ - "chrysanthème" in French; /ðəひ/ "though" in English), dictations become necessary to assess spelling knowledge.

\subsection{How do we produce written content in French when we have to write a dictation?}

When we write, stored graphemic information is activated to produce content. It is related to spelling knowledge; two different users can write words differently according to their spelling level (Caramazza, 1991). Spelling can be done in speech (when we spell words out loud) and in written production (when we write a word).

Information in input is always processed through the auditory channel (Caramazza, 1991) and includes two different kinds of information processing: (a) The first allows processing new words, or non-words, and relies on auditory and phonetic processors that activate small units in working memory where information is stored within a very brief time. Information stored in phonologic buffers is submitted to graphemic buffers to allow activating the phoneme-to-grapheme correspondence. That is how information in input becomes either a spoken or written output. (b) The latter allows processing familiar words, but includes another process that looks like the first one. After auditory and phonetic processing, information in input is analyzed in the phonological and/or semantic lexicon, which is stored in long-term memory. Then, there are two different solutions. Information processing ends with an output that comes either from the phonologic or the graphemic lexicon.

Differences may occur between spoken and written words. Some words in French include letters that have no phonic value (the " $t$ " in the word "salut"). But the same phoneme may be written differently, like the phoneme /s/ for which there are seven graphemes in French ("s" in "son"; "c" in "cinq"; "ç" in "hameçon"; the double consonent "ss" in "basse"; "sc" in "piscine"; " $\mathrm{t}$ " in "addition" and " $\mathrm{x}$ " in "dix").

Some graphemes are very specific because they carry a meaning. We are talking about morphemes, which are defined as the smallest units of meaning (Cellier, 2003). When it comes to choosing the correct spelling in French, some morphemes become very difficult to write, since they are parts of non-homographic homophones, which are words that are pronounced in the same way but spelled differently (Kerswell, Siakaluk, Pexman, Sears, \& Owen, 2007). The morphemes /e/ and / / / at the end of verbs and adjectives in French are an example. Knowing how to correctly spell these words is a matter of semantic context, since ten different forms can encode the same sound ("parler"; "parlez"; "parlé"; "parlée"; "parlés"; "parlées"; "parlaii"; 
"parlais"; "parlait"; "parlaient" [to speak]). When there is a homophone situation, several different spelling representations will be activated for one phonological representation. The user will then have to select the one that best applies to the context (Kerswell et al., 2007). The choice between the activated and competing phonological representations will be made by going back and forth between phonologic, semantic, and orthographic information. If the input is for example /a/, phonological information is the first activated, then semantic information: is it a verb "il a une voiture rouge" (he has a red car) or a preposition? "Il va à Paris" (he is going to Paris), and then orthographic information ("a"/ "à").

The competition between two (or more) non-homographic homophones is correlated to their frequency of use in a given language ("à" would be more confused with "a" than "as", or "to" with "too" rather than "two") (Kerswell et al., 2007). This is called the "homophonic magnitude" (Coltheart, Patterson, \& Leahy, 1994).

Lots of non-homographic homophones in French are a matter of plural and/or gender inflection (see the example of the verb "parler" supra). If these words are spoken out separately (if they are quoted out of context as individual items, at a morphological level rather than at a syntactic level, it becomes impossible to know whether it is the singular or plural form (c.f. "parent"/ "parents", since the "s" is silent). This may explain the amount of misspellings that can occur. As a consequence, when some words are usually written in the plural form, they will be written down in their plural form even in a singular context. As "parents" is frequently used in the plural form, writing "un parent" - which means "the parent" may lead writers to produce "un parents" (Largy, Cousin, Bryant, \& Fayol, 2007, who called it the "effect of congruity").

But French spelling is not just a matter of exceptions and irregularities. French is defined as phonogrammic, since one phoneme is equivalent to one grapheme in more than $80 \%$ of the cases (Catach, 1980). This theory is linked to the seven different values a letter can get in French (Blanche-Benveniste \& Chervel, 1969):

(a) The basic value: the most used value for a given letter ("s" usually encodes the sound /s/ in French);

(b) The zero value that we mentioned supra: a given letter has no phonic value (the " $t$ " in "aspect" is silent in French);

(c) The position value: the phonic value depends on the context where the letter is produced (the "s" in "précise" in French, where the "s" is located between two vowels and is consequently pronounced /z/);

(d) Digraphs and trigraphs, which are groups of two or three letters that together form a new phoneme, which is different from the basic value of each letter ("on" in "son" in French; "ai" in "chair" in English"); 
(e) Grammatical and lexical morphemes (the "s" in the word "avais" is a grammatical morpheme; "jardin" allows creating "jardinant", "jardinière", etc. where "ant" and "ière" are lexical morphemes in French).

As phonic and graphemic knowledge is mainly used at the same time to ensure information processing and as phonic knowledge is activated before semantic and orthographic knowledge (Caramazza, 1991), some interference may occur. This may lead to the production of misspellings. The question naturally arises about what happens when using text or instant messaging and how it may have consequences on spelling production.

\section{The use of digital writing: what kind of effect on spelling?}

At the beginning of the twenty-first century, texting was the first form of digital writing to be studied. The use of texting was first considered to be linked to the cost of texts, which were limited to 160 characters (Pétillon, 2006). But it cannot explain the instant message particularities because the wide distribution of unlimited monthly plans which include unlimited texts (in several countries, particularly in France) did not put an end to digital writing. Moreover, instant mobile messaging applications (i.e., WhatsApp, Petitjean \& Morel, 2017, Viber...) or email (Volckaert-Legrier, Bernicot, \& Bert-Erboul, 2009) are also concerned by the use of this lexicon. Digital writing has also been studied for its social aspects (Bonetti, Campbell, \& Gilmore, 2010; Bryant, Sanders-Jackson, \& Smallwood, 2006; Sjöberg, 2003; Valkenburg \& Soeters, 2001). The recent study by Khiari, Bouhafs, \& Roche (2016) on the evocation of SMS sentiments, from the corpus 88 milSMS, has shown that repetitions of characters (merciiiiiiii [thanks] Bizouuuuuu [kiss]) or punctuation marks (yes !!!!!!!!) often carry feelings and allow to appreciate the valence and emotional intensity of the message.

These definitions have helped to understand why spelling standards may sometimes be modified. Writing using digital media indeed becomes an act of immediacy in communication and the answer is expected quickly, as in face-to-face conversation (Anis, 2003; Fernandez \& Yuldashev, 2011). Today, the economic aspect is not as central as time-saving (Anis, 2003) and sociocultural aspects (Haggan, 2007; Rivière \& Licoppe 2005).

Lately, several studies have tried to understand if using digital writing may have an effect on the quality of spelling production (Goumi \& Bernicot, 2012; Lanchantin, Simoës-Perlant, \& Largy, 2015). Scientific results differ, as:

(a) No negative impact has been found. The authors show that the users have a pluricompetence to switch between traditional and digital writing according to the register (e.g.: Anderson \& Elsner, 2014; Bernicot, Goumi, Bert-Erboul, \& Volckaert-Legrier, 
2014; De Jonge \& Kemp, 2012; Maskens, Cougnon, Roekhaut, \& Fairon, 2015; Plester \& Wood, 2009; Plester, Wood, \& Joshi, 2009; Wood, Jackson, Plester, \& Wilde, 2009; Wood, Kemp, Waldron, \& Hart, 2014) for good spellers (e.g.: Lanchantin, Simoës-Perlant \& Largy, 2012a; Plester, Wood, \& Bell, 2008; Powell \& Dixon, 2011).

(b) Some authors showed that nothing can be concluded for bad spellers as some modifications can be confused with misspellings (Bouillaud, Chanquoy, \& Gombert, 2007; Febvrel \& Hureau, 2008; Lanchantin et al., 2012a). In contrast, other modifications may never be produced in standard writing (e.g.: Anis, 2003 "consonant clippings/contractions", as for "slt" instead of "salut").

(c) Some authors mentioned that texting may have a negative effect on spelling production because of the negative influence from the media that may have consequences on spelling performance for some people (Drouin \& Davis, 2009; Zahid \& Mehmood, 2013).

These differences might be attributed to the methods that have been used (e.g.: Drouin, 2011, verbal and non-verbal testing; spelling scores, etc.).

Our research study has been designed to learn about the effect of using instant messaging (especially regarding the quality of spelling production). We chose not to use the term of "textism" but "modification" to refer to the words that are modified and not "texting" but "digital writing" to refer to the whole production of modifications that can/cannot be confused with misspellings (Lanchantin, SimoësPerlant, \& Largy, 2012b). We have started from the differences in terms of results mentioned supra. This led us to know more about this effect on spelling production, which may differ according to the type of modification. In other words, some modifications, once used, may indeed have an effect on the quality of spelling, whereas others do not. We will then focus on the type of modification (i.e. that can/cannot be confused with misspellings). Our hypothesis is that there will be more modifications that can be confused with misspellings than modifications that cannot, in both corpora. If this hypothesis is confirmed, it will show that the nature of the link between the use of digital writing in instant messaging and spelling production differs according to the type of modification. This work aims at restricting the scope on modifications that can really decrease the quality of spelling production, to better analyze future corpora.

\section{Method}

\subsection{Participants}


The "Archives Départementales" of Montauban (a French town) gave us free access to 119 archived documents of the French national certificate of general education written in 1974 (i.e. before digital writing appears). As these documents are anonymized, we were unable to gather data related to gender or age for this sample. One-hundred and nineteen 9th grade students participated in the study in 2012 (55 boys; 64 girls) (i.e. after digital writing appears). They had an average age of 14.70 $(\mathrm{SD}=0.65)$. We received consent from all the adolescents and their parents. We ensured all participants used digital writing every week. For that, the adolescents who participated in 2012 were asked to complete a questionnaire that focuses on reading and writing habits in standard and digital writing (cf., Appendix A).

\subsection{Ethical clearance and conflict-of-interest disclosure}

We followed the French "Behavioral Science Ethics Code" (Caverni, 1998). Since minor participants were recruited for research study, we first asked for the school principal's permission. Then, we asked for the agreement of a parent or legal guardian to allow the child to participate in the research. Every adolescent who participated in the study gave his/her free and informed consent and protection of their identity was guaranteed. Furthermore, we mentioned that they could leave the scientific process at any time.

Our material was built in such a way as to leave no misunderstanding or uncertainty on any matter at all. We ensured no one would feel shocked or hurt by the content of the material. The objective of the study was clearly defined and presented to the participants.

We accepted to communicate all our results to the school principal, who was to provide this information to the participants. No personal data has been used and participants were told so.

We were not bound to any company by an employment contract and did not receive any financial support for conducting this study. Administratively speaking, we only had to ask for the Inspection-Académique (i.e. the local education authority), the school principal's, and the French teachers' permissions to meet the students. The method and approach has been peer reviewed to manage conflict of interest and to guarantee that ethical basic principles were scrupulously followed.

Students were invited to participate in the study during two hours and they did not receive financial contribution for their participation. However, they were motivated to participate in the study as they had to sit the same examination, i.e. a dictation at the end of the month.

\subsection{Material and procedure}


The dictation is a text of Robert Sabatier intitled "Partage". We ensured both groups wrote the dictation at the same time of year. We also checked their spelling level. The dictation was exactly the same in 1974 and 2012 and it contained 206 words (cf., Appendix B).

We followed the instructions provided for the French National diploma examination by: (a) re-reading the dictation; (b) writing proper nouns on the blackboard; (c) inviting participants to write the dictation and read it at the end; and (d) reading the dictation again.

\subsection{Results}

Data were gathered in a typology that we designed for the study. It is based on previous works in instant messaging (Lanchantin, Simoës-Perlant, \& Largy, 2014, $f$. Table 1). Two types of modifications were considered: Modifications that can be confused with misspellings and modifications that cannot be mistaken for misspellings (cf. Table 1).

The structure of this typology was conceived according to the main criterion that is the alteration / non-alteration of the phonic value (Simoës-Perlant et al., 2012). This criterion made it possible to distinguish three parts within this typology corresponding to the types of modification. As a result, some categories differ from other typologies in SMS language since we considered the phonological and semiotic modifications to construct our typology.

Several elements had to be taken into consideration before the data were coded. Indeed, for the complex phenomenon (i.e., "pô" for "pas"), we counted and classified several modifications (graphical reduction with a mute-word ending and a phonetic substitution with variation).

This typology has been submitted to an interrater reliability calculation, which showed acceptable tolerance (the kappa coefficient was 0.941).

Table 1. Typology of Lanchantin, Simoës-Perlant and Largy (2014)

Modifications that can be mistaken for misspellings

\section{Modifications that cannot be mistaken formisspellings}

\begin{tabular}{llll}
\hline \multicolumn{4}{c}{ Additions } \\
\hline Addition of letters or diacritical sign : "les & Addition of & & \\
zamis » ("les amis" [the friends]) & "!!!!!!!!” & & \\
& Copied-pasted & \\
\hline
\end{tabular}




\section{Substitutions}

Substitutions on several words (spaces instead of hyphens):

"c'est à dire" ("c'est-à-dire" [that is to say])

Graphic overwriting

"quil" ("qu'il" [it])

Homophones: “ $a$ ” (“ $a ̀$ ”)

Grapheme substitutions:

Digraph $\rightarrow$ letter: "dégouté" ("dégouter"

[to disgust])

Trigraph $\rightarrow$ letter: "bo" ("beau”

[beautiful])

Letter $\rightarrow$ another letter; digraph $\rightarrow$

another digraph; trigraph $\rightarrow$ another

trigraph: "dégouter" ("dégoutez”)

Grapheme substitutions:

Letter $\rightarrow$ digraph: "dégoutés"

("dégouté")

Letter $\rightarrow$ trigraph: "dégoutais"

("dégouté")

Double consonants $\rightarrow$ one consonant:

"dificile" ("difficile" [difficult])

Lack of letters in final position with no

phonic value: "salu" ("salut" [hi])

\section{Alterations/Reductions}

Grapheme alterations/reductions:

Digraph $\rightarrow$ letter: "ui" ("oui" [yes])

Trigraph $\rightarrow$ letter: "métenant"

("maintenant" [now])

Letter $\rightarrow$ another letter; digraph $\rightarrow$

another digraph; trigraph $\rightarrow$ another

trigraph: "ca" /ka/ ("sa" /sa/)
Whole substitutions of one word by the name of a letter, or the arithmetic name of a symbol: "c" ("c'est" [it is]), "1"

("un")

Variations within a word:

"bisoo" - "oo" is a digraph in English, not in French - ("bisous" [kisses])

Anglicism : "love” ("amoureux”)

Grapheme alterations/reductions:

Reductions on several words: 


\begin{tabular}{|c|c|}
\hline $\begin{array}{l}\text { Letter } \rightarrow \text { digraph: "biso" ("bisous" } \\
\text { [kiss]) } \\
\text { Letter } \rightarrow \text { trigraph }\end{array}$ & 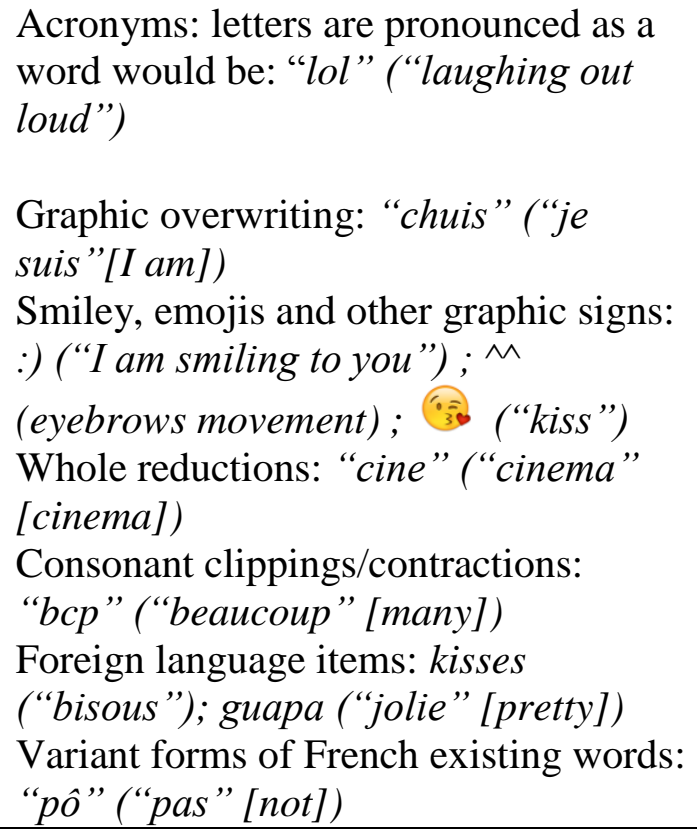 \\
\hline
\end{tabular}

An ANOVA was conducted, with 2 (Group: 1974 vs. 2012) x 3 (Phenomenon: Addition vs. Substitution vs. Alterations/Reductions) x 2 (Type: Modifications that can be mistaken for misspellings vs. Modifications that cannot be mistaken for misspellings). The dependent variable was equal to the rate of misspellings produced (by total number).

For any type of modifications, the group effect is significant, $F(1,236)=$ $186.63, p<.001, \eta^{2} p=.44$. The percentage of overall modifications is higher in 2012 corpus $(2.29 \%$ [0.1]) than in 1974 one $(0.57 \%$ [0.1]). The results confirm the hypothesis that the percentage of modifications that can be mistaken for misspellings $(2.86 \%$ [0.13]) is higher than the percentage of modifications that cannot $(0.01 \%)$, $F(1,236)=517.91, p<.001, \eta^{2} \mathrm{p}=.69$. A significant difference exists between the substitutions, additions and alteration/reductions, $F(2,472)=519.44, p<.001, \eta^{2} \mathrm{p}=$ .69. The group $\mathrm{x}$ type $\mathrm{x}$ phenomenon interaction is significant, $F(2,472)=170.25, p<$ $.001, \eta^{2} \mathrm{p}=.41$.

The sub-plan analysis shows:

a) For the modifications that can be mistaken for misspellings, the difference between the two groups is significant, $F(1,236)=186.90, p<.001, \eta^{2} \mathrm{p}=.44$.

Students who wrote the dictation in 1974 made fewer misspellings than those who wrote the dictation in 2012 (1.14\% [1.8] vs. 4.6\% [1.8]). A significant difference exists between the substitutions, additions and alteration/reductions, $F(1.236)=$ $73.72, p<.001, \eta^{2} \mathrm{p}=.24$. This effect interacts with the group, $F(1.236)=37.43, p<$ 
$.001, \eta^{2} p=.14$. In the 1974 as in the 2012 corpus, the phenomenon effect is significant, the substitutions are higher than alterations/reductions and additions. These percentages are still significantly higher in 2012 than in 1974 ( $c f$. Table 2). b) For the modifications that cannot be mistaken for misspellings, no significant difference is shown as a function of the group or type of phenomenon used.

Table 2. Percentage of additions, substitutions and alterations/reductions that can be mistaken for misspellings in 1974 and 2012 corpora

\begin{tabular}{lrrr}
\hline & Group & \multicolumn{1}{c}{$\begin{array}{c}\text { Mean } \\
(\%)\end{array}$} \\
Additions & \multicolumn{2}{c}{ SD } \\
& 1974 &, 01 &, 06 \\
Substitutions & 2012 &, 24 &, 33 \\
& 1974 & 3,24 & 1,87 \\
Alterations/Reductions & 2012 & 12,30 & 7,08 \\
& 1974 &, 17 &, 45 \\
& 2012 & 1,22 & 1,40 \\
\hline
\end{tabular}

\section{Discussion}

The aim of this study was to show that the nature of the link between the use of digital writing in instant messaging and the quality of spelling production may differ according to the kind of modification (i.e. that can/cannot be mistaken for misspellings).

If we focus on the modifications that cannot be mistaken for misspellings, no significant difference was found between the two corpora. This means using this type of modification (i.e., "svt" pour "souvent" [often]) has no effect on the quality of spelling production and, as a consequence, no effect on the content of the orthographic lexicon.

Our results have no equivalent in the literature, because no research has differentiated between modifications that can be mistaken for misspellings or not. Nevertheless, they are, in a certain way approaching the conclusion of Bernicot et al. (2014), who consider that the use of a specific register leads to new conventions. Our results add another argument to the claim that digital writing is not responsible of the deterioration of traditional writing. This is because no connection between the use of digital writing and the quality of spelling production is shown (De Jonge \& Kemp, 
2012; Plester et al., 2008; Plester \& Wood, 2009; Plester et al., 2009; Powell \& Dixon, 2011; Wood et al., 2009; Wood et al., 2014).

If we focus more precisely on the percentage of modifications that can be mistaken for misspellings, the results are different. In fact, this type of modifications has increased between 1974 and 2012 (3.42\% [2.06] in 1974 vs. 13.75\% [7.98] in 2012). This means that the spelling level has decreased between 1974 and 2012. Can digital writing have a negative impact on standard writing for this type of modification in particular? In French, there are sometimes multiple candidates for one word (e.g.: "a" instead of "à" in the sentence "Bouboule tenait à la main" [Bouboule held in his hand]) and the phoneme-to-grapheme correspondence is sometimes irregular what may lead to the production of misspellings (e.g.: "compartimant" instead of "compartiment" [compartment]). When putting thoughts into words in the actual 'writing' step (Hayes \& Flower, 1980) written candidates for what is formulated by the 'inner voice' and held in WM are retrieved from the orthographic memory. If this process is made in digital writing, the user is freer when matching phonology in the 'inner voice' to the written form as the appropriate candidate is selected on the basis of phonology only. The criteria of selection being that the retrieved form should be pronounced in a way corresponding to the message formulated by the 'inner voice'. Therefore, if the modifications that can be mistaken for misspellings are frequently used in digital writing, this can damage the content of the orthographic lexicon, at least more than when the user only produces standard writing. The works on the implicit learning of spelling are important. Indeed, the sensitivity to orthographic regularities, as well as the recovery of instances (Cousin, Thibault, Largy, \& Fayol, 2006), emanate largely from the exploitation of statistical language regularities. Linguistic stimuli would be stored as they were encountered and the quality of their storage would depend on the frequency of exposure to these stimuli (Lété, 2006). In addition, according to the theory of self-learning of Share (1995), each successful decoding of an unknown word provides the opportunity to acquire the spelling information specific to that word. Thus, the different sources of information (lexical, phonological or morphological), which are confronted by children very early are all accelerators of the development of orthographic skills.

\section{Conclusion}

If these results are analyzed jointly, there would be two kinds of links between the use of digital writing in instant messaging and the quality of spelling production. When the user produces modifications that can be confused with misspellings, it may generate a huge impact on cognitive resources, of which the orthographic lexicon is a 
part but when s/he produces modifications that cannot be confused with misspellings, no impact is generated.

In future research, it would be interesting to be able to continue the corpora comparison of young teens, both past and present, using digital writing data corpora emanating for example from SMS4science (http://www.sms4science.org/), sud4science/88milSMS (http://www.sud4science.org/, http://88milsms.huma-num.fr/), CoMeRe (https://corpuscomere.wordpress.com/), What's up Switzerland (http://www.whatsup-switzerland.ch/index.php/fr/) or Vos Pouces pour la Science (http://www.vospouces.org/). These data would provide additional elements to the debate about the impact of the use of digital writing on students' spelling performance.

\section{References}

Anderson, H., \& Elsner, R. J. (2014). Exposure to "textisms" does not lower spelling scores for elementary school aged children. Current Research in Psychology, 5(2), 89-95. doi:10.3844/crpsp.2014.89.95

Anis, J. (2003). Communication électronique scripturale et formes langagières. Paper presented at the Actes des Quatrièmes Rencontres Réseaux humains / Réseaux technologiques. Retrieved December 11th, 2010, from http://rhrt.edel.univpoitiers.fr/document.php?id=547.

Baddeley, A. D., \& Hitch, G. (1974). Working memory. In G.H. Bower (Ed.), The psychology of learning and motivation: Advances in research and theory $(8,47-$ 89). New York: Academic Press.

Baddeley, A. (2000). The episodic buffer: a new component of working memory? Trends in cognitive sciences, 4 (11), 417-423. doi : 10.1016/S13646613(00)01538-2

Bernicot, J., Goumi, A. \& Bert-Erboul. A. Volckaert-Legrier, O. (2014). How do skilled and less-skilled spellers write text messages? A longitudinal study. Journal of Computer Assisted Learning. doi: 10.1111/jcal.12064

Blanche-Benveniste, C., \& Chervel, A. (1969). L'orthographe. Paris: Maspero.

Bonetti, L., Campbell, M.A., \& Gilmore, L. (2010). The relationship of loneliness and social anxiety with children's and adolescents' online communication. Cyberpsychology, Behavior and Social Networking, 13(3), 279-285. doi: 10.1089/cyber.2009.0215

Bouillaud, C., Chanquoy, L., \& Gombert, J.-E. (2007). Cyberlangage et orthographe: quels effets sur le niveau orthographique des élèves de CM2, 5ème et 3ème? Bulletin de Psychologie, 60(6), 553-565. doi:10.3917/bupsy.492.0553 
Bryant, J. A., Sanders-Jackson, A., \& Smallwood, A. M. (2006). IMing, text messaging, and adolescent social networks. Journal of Computer-Mediated Communication, 11(2), 577-592. doi: 10.1111/j.1083-6101.2006.00028.x

Caramazza, A. (1991). The role of the graphemic buffer in spelling: Evidence from a case of acquired dysgraphia. Neuropsychology and Cognition, 3, 269-295. doi : 10.1007/978-94-011-3740-9_8

Catach, N. (1980). L'orthographe française : traité théorique et pratique avec des travaux d'application et leurs corrigés. Paris: Nathan.

Caverni, J.-P. (1998). Un code de conduite des chercheurs dans les sciences du comportement. L'année psychologique, 98(1), 83-100. doi:10.3406/psy.1998.28612

Cellier, M. (2003). Orthographe. In M. Prouilhac (Ed.), Savoirs et culture (193-247). Toulouse: CNED.

Coltheart, V., Patterson, K., \& Leahy, J. (1994). When a ROWS is a ROSE: Phonological effects in written word comprehension. Quarterly Journal of Experimental Psychology (A: Human Experimental Psychology), 47, 917-955. doi: 10.1080/14640749408401102

Cousin, M. P., Thibault, M. P., Largy, P., \& Fayol, M. (2006). Apprentissage de la morphologie flexionnelle du nombre nominal: étude de la récupération d'instances chez des enfants tout-venant et des enfants présentant un trouble de l'apprentissage de l'écrit. Rééducation orthophonique, 44(225), 93-109.

De Jonge, S. \& Kemp, K. (2012). Text-message abbreviations and language skills in high school and university students. Journal of Research in Reading, 35(1), 49-68. doi: 10.1111/j.1467-9817.2010.01466.x

Dresner, E., \& Herring, S. C. (2010). Functions of the Nonverbal in CMC : Emoticons and Illocutionary Force. Communication theory, 20, 249-268. doi:10.1111/j.1468-2885.2010.01362.x

Drouin, M. A. (2011). College students' text messaging, use of textese and literacy skills. Journal of Computer Assisted Learning, 27(1), 67-75. doi:10.1111/j.13652729.2010.00399.x

Drouin, M. A. \& Davis, C. (2009). R u txting? Is the Use of Text Speak Hurting Your Literacy? Journal of Literacy Research, 41(1), 46-67. doi:10.1080/10862960802695131

Fairon, C., Klein, J. R., \& Paumier, S. (2006). Le langage SMS : étude d'un corpus informatisé à partir de l'enquête : Faîtes dons de vos SMS à la science.

Louvain : Presses Universitaires de Louvain.

Febvrel, A., \& Hureau, C. (2008). "Msn c tro bi1?": Influence de la communication médiée par ordinateur sur les pratiques orthographiques: étude auprès d'une population de CM2. Unpublished master's thesis. 
Fernandez, J. \& Yuldashev, A. (2011). Variation in the Use of General Extenders and Stuff in Instant Messaging Interactions. Journal of Pragmatics, 43(10), 26102626.

Flower, L. \& Hayes, J. R. (1981). A cognitive process theory of writing. College Composition and Communication, 32(4), 365-387.

Goumi, A. \& Bernicot, J. (2012). Le langage SMS chez les adolescents, faut-il s'en inquiéter? L'école numérique, 12, 34-35.

Haggan, M. (2007). Text messaging in Kuwait. Is the medium the message? Multilingua, 26(1), 427-449.

Hayes, J. R. (1996). A new framework for understanding cognition and affect in writing. In C.M. Levy and S. Ransdell (Eds.), The science of writing (1-27). Mahwah (NJ): Erlbaum.

Hayes, J. R., \& Flower, L. S. (1980) Identifying the organization of writing processes. In L. W. Gregg, \& E. R. Steinberg (Eds.), Cognitive processes in writing (pp. 3-30). Hillsdale, NJ: Lawrence Erlbaum.

Kerswell, L., Siakaluk, P. D., Pexman, P. M., Sears, C. R., \& Owen, W. J. (2007). Homophone Effects in Visual Word Recognition Depend on Homophone Type and Task Demands. Canadian Journal of Experimental Psychology, 61(4), 322327. doi: $10.1037 /$ cjep2007032

Khiari W., Bouhafs A., \& Roche M. (2016). Comment prendre en compte les spécificités de "l'écriture SMS" pour l'analyse de sentiments? In Proceedings JADT (Journées internationales d'Analyse statistique des Données Textuelles), Nice, France, 2016

Kobus, C., Yvon, F., \& Damnati, G. (2008). Transcrire les SMS comme on reconnaît la parole /Electronic Version/. TALN 2008. Retrieved July 11th, 2011, from ftp://tlp.limsi.fr/public/013 taln_1364.pdf

Lanchantin, T., Simoës-Perlant, A., \& Largy, P. (2015). De la relation de l'écrit numérique et la qualité de l'orthographe. Glossa, 118, 40-57.

Lanchantin, T., Simoës-Perlant, A., \& Largy, P. (2012a). DWIM typology (Digital Writing in Instant Messaging) based on the spelling level of French 7th grade students. Paper presented at the International Psychological Applications Conference and Trends 2012, Lisbon.

Lanchantin, T., Simoës-Perlant, A., \& Largy, P. (2012b). The case of Digital Writing in Instant Messaging: when cyber written productions are closer to the oral code than the written code. PsychNology, 10(3), 187-214.

Largy, P., Cousin, M.P., Bryant, P., \& Fayol, M. (2007). When memorized instances compete with rules: the case of number-noun agreement in written French. Journal of Child Language, 34, 425-437. doi: 10.1017/S0305000906007914 
Liénard, F. (2008). Analyse linguistique et sociopragmatique de l'écriture électronique : le cas du SMS tchaté. In J. Gerbault (Ed.), La langue du cyberespace: de la diversité aux normes (pp. 265-278). Paris : L'Harmattan.

Maskens, L., Cougnon, L.A., Roekhaut, S., \& Fairon, C. (2015). Nouveaux médias et orthographe. Incompétence ou pluricompétence ? Discours [En ligne], mis en ligne le 09 septembre 2015, consulté le 30 septembre 2016. URL : http://discours.revues.org/9020. doi: 10.4000/discours.9020

Ong'onda, N. A., Matu, P. M., \& Oloo, P. A. (2011). Syntactic Aspects in Text Messaging. World Journal of English Language, 1(1), 2-8. doi:10.5430/wjel.v1n1p2

Panckhurst, R. (2009). Short Message Service (SMS) : typologie et problématiques futures. Polyphonies, 33-52.

Petitjean, C. \& Morel, E. (2017). "Hahaha": Laughter as a Resource to Manage WhatsApp Conversations. Journal of Pragmatics, 110, 1-19.

Pétillon, S. (2006). Le discours SMiste, un nouveau corpus ? [Electronic Version]. Dossier "Orthographe", 440.

Plester, B., \& Wood, C. (2009). Exploring relationships between traditional and new media literacies: British preteen texters at school. Journal of Computer-Mediated Communication, 14, 1108-1129. doi:10.1111/j.1083-6101.2009.01483.x

Plester, B., Wood, C., \& Bell, V. (2008). Txt msg n school literacy: does texting and knowledge of text abbreviations adversely affect children's literacy attainment? Literacy, 42 (3), 137-144. doi:10.1111/j.1741-4369.2008.00489.x

Plester, B., Wood, C., \& Joshi, P. (2009). Exploring the relationship between children's knowledge of text message abbreviations and school literacy outcomes. The British Psychological Society, 27, 145-161. doi:10.1348/026151008X320507

Powell, D., \& Dixon, M. (2011). Does SMS text messaging help or harm adults' knowledge of standard spelling? Journal of Computer Assisted Learning, 27(1), 58-66. doi:10.1111/j.1365-2729.2010.00403.x

Rivière, C. A. \& Licoppe, C. (2005). From voice to text: Continuity and change in the use of mobile phones in France and Japan. In Harper, R. (éd.) The inside text. Dordrecht (Springer), 103-126.

Simoës-Perlant, A., Thibault, M.-P., Lanchantin, T., Combes, C., Volckaert-Legrier, O., \& Largy, P. (2012). How adolescents with dyslexia dysorthographia use texting. Written Language and Literacy, 15(1), 65-79. doi:10.1075/wll.15.1.04sim

Sjöberg, U. (2003). Making sense of screen-based media. The uses and readings of television, computer games, and Internet among swedish young people. In I. Rydin (Ed.). Media fascinations: Perspectives on young people's meaning making (147164). Goteborg: Nordicom. 
Valkenburg, P. \& Soeters, K. (2001). Children's positive and negative experiences with the Internet: An exploratory survey. Communication Research, 28(5), 652675. doi:10.1177/009365001028005004

Véronis, J., \& Guimier de Neef, E. (2006). Le traitement des nouvelles formes de communication écrite. In G. Sabah (Ed.), Compréhension automatique des langues et interaction (pp. 227-248). Paris : Hermès Science.

Volckaert-Legrier, O., Bernicot, J. \&, Bert-Erboul, A. (2009). Electronic Mail, a new written-language register: a study with French-speaking adolescents. British Journal of Developmental Psychology, 27, 163-181.

Wood, C., Jackson, E., Plester, B., \& Wilde, L. (2009). Children's use of mobile phone text messaging and its impact on literacy development in primary school [Electronic Version]. Retrieved September $18^{\text {th }}, 2013$ from

http://research.becta.org.uk/index.php?section=rh\&catcode=_re_rp_02\&rid=16824

Wood, C., Kemp, N., Waldron, S., \& Hart, L. (2014). Grammatical understanding, literacy and text messaging in school children and undergraduate students: A concurrent analysis. Computers \& Education, 70, 281-290. doi:10.1016/j.compedu.2013.09.003

Yvon, F. (1998). Rewriting the orthography of SMS messages. Natural Language Engeneering, 1(1), 1-28. doi:10.1017/S1351324909990258

Zahid, Y. \& Mehmood, A. (2013). Effects of SMS on Writing Skills of the University Students in Pakistan (A Case Study of University of Gujrat). Asian Economic and Financial Review, 3(3), 389-397. http://www.aessweb. com/pdf-fi les/389-397.pdf. 


\section{Appendix A: Questionnaire on the reading and writing habits in traditional and digital writing}

Code:

Age:

Grade:

\begin{tabular}{|c|c|c|}
\hline $\mathbf{N}^{\circ}$ & Question & $\begin{array}{l}\text { Answer } \\
\text { (please circle } \\
\text { it) }\end{array}$ \\
\hline 1 & Do you have access to the Internet at home? & YES NO \\
\hline 2 & Do you have internet access at home? & YES NO \\
\hline 3 & Have you ever read a blog? & YES NO \\
\hline 4 & Have you ever left a comment on a blog? & YES NO \\
\hline 5 & Have you ever written a blog of your own? & YES NO \\
\hline 6 & Do you know and use instant messaging? & YES NO \\
\hline 7 & Do you know how to use smileys? & YES NO \\
\hline 8 & Do you know how to use shortcuts and abbreviations? & YES NO \\
\hline \multirow[t]{6}{*}{9} & $\begin{array}{l}\text { What websites/social network sites do you use for instant } \\
\text { messaging (this question allows multiple answers): }\end{array}$ & \\
\hline & Facebook & YES NO \\
\hline & Google Hangouts & YES NO \\
\hline & Instagram/InstaMessage & YES NO \\
\hline & Twitter & YES NO \\
\hline & Skype & YES NO \\
\hline 10 & Do you send texts or instant messages most days? & YES NO \\
\hline 11 & Do you log onto social network sites most days? & YES NO \\
\hline 12 & Do you often post comments on social network sites? & YES NO \\
\hline 13 & Do you have your own cellphone? & YES NO \\
\hline 14 & $\begin{array}{l}\text { When you send texts or instant messages, do you pay attention } \\
\text { to spelling? }\end{array}$ & YES NO \\
\hline 15 & $\begin{array}{l}\text { Do you have difficulties in making sense of other people's texts } \\
\text { or instant messages? }\end{array}$ & YES NO \\
\hline 16 & To send instant messages, you (this question allows only one & \\
\hline
\end{tabular}




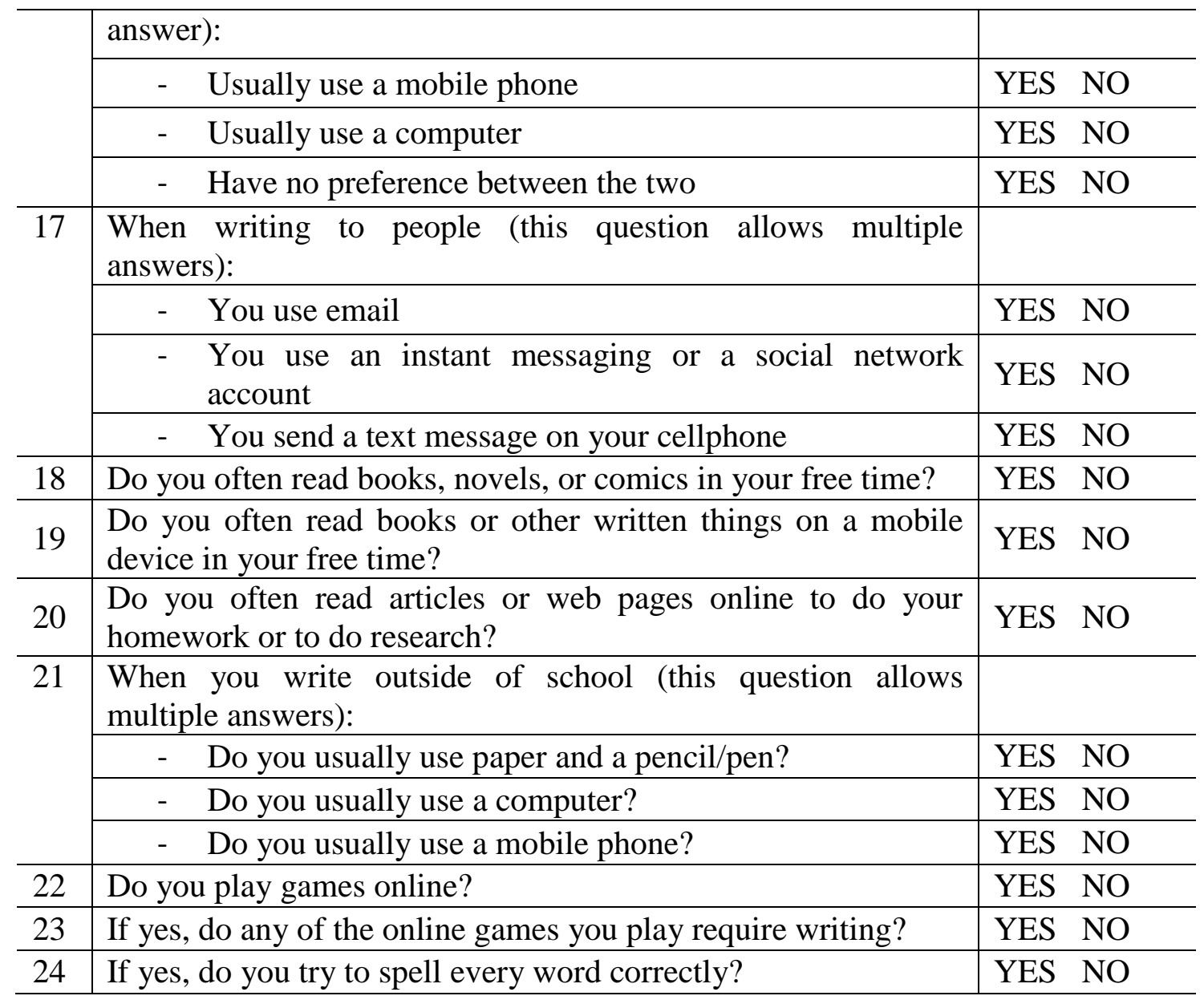




\section{Appendix B: Dictation of Robert Sabatier intitled "Partage"}

\section{Partage}

Une voix fraîche interpella Olivier. C'était son voisin de classe, un nommé Dédé, mais qu'on appelait Bouboule, petit être obèse et joyeux qui passait son temps à s'empiffrer de chaussons aux pommes, de pains au chocolat, et de toutes sortes de sucreries sans la moindre gêne. Ses goûters de quatre heures étaient célèbres : de véritables repas de déménageur. Toute sa vie, il ressemblerait à un hippopotame. Si on se moquait de lui, il répondait avec un sourire niais, et tapait sur son ventre avec un bon regard qui désarmait. Au fond, Bouboule, on l'aimait bien.

- « Vise un peu cette glace !»

Bouboule tenait à la main un cornet à double compartiment, où deux boules de glace en supportait une troisième. Tout en parlant, il lapait la vanille, la fraise et le café, indifféremment à coups de langue rapides et ses yeux roulaient de gourmandise satisfaite.

- «Tu m’en files ? » demanda Olivier. Généreusement, Bouboule fit glisser la boule de glace à la fraise dans la paume de son camarade. Ils se mirent à rire. Parce que c'était froid, Olivier faisait passer la glace d'une main dans l'autre et, en même temps, il léchait la crème qui fondait. Ils sautèrent, ils gambadèrent..."

Robert Sabatier. 


\section{Acknowledgements}

We want to thank the "Archives Départementales" of the town of Montauban, who gave us free access to the corpus of dictation written in 1974, but also all the students, parents, teachers, and school principal for their participation to the study. 


\begin{abstract}
Instant messaging, digital writing and spelling production quality in French? A cognitive approach

The increased use of digital writing has led to the emergence of written forms that may differ from the standards of spelling. When these forms differ from standard spelling, two types have been distinguished: (a) those that can be confused with misspellings and (b) those that cannot. Our diachronic research protocol compared two corpora (from 1974 and 2012). The results showed that when a modification has no orthographic equivalent, its use cannot damage the quality of spelling production. When it does, the effect on spelling may be negative as an implicit learning based on frequency of exposure seems to take place.
\end{abstract}

Keywords: standard writing; instant messaging; adolescent; spelling; digital writing.

\title{
Author(s) address
}

Aurélie Simoës-Perlant

Université de Toulouse Jean Jaurès

Laboratoire CLLE CNRS UMR5263

5 Allées Antonio Machado

31058 Toulouse Cedex 9.

simoes@univ-tlse2.fr

Tonia Lanchantin

Université de Toulouse Jean Jaurès

Laboratoire OCTOGONE-Lordat, EA4156

5 Allées Antonio Machado

31058 Toulouse Cedex 9.

tlanchan@univ-tlse2.fr

Cecilia Gunnarsson-Largy

Université de Toulouse Jean Jaurès

Laboratoire OCTOGONE-Lordat, EA4156

5 Allées Antonio Machado

31058 Toulouse Cedex 9. 
gunnars@univ-tlse2.fr

Pierre Largy

Université de Toulouse Jean Jaurès

Laboratoire OCTOGONE-Lordat, EA4156

5 Allées Antonio Machado

31058 Toulouse Cedex 9.

largy@univ-tlse2.fr 